\title{
CASA ESSAY
}

The paper judged to be the best student essay submitted to Akroterion by 30 November preceding publication of the volume for that specific year, is published annually as the CASA Essay (formerly called the B X de Wet Essay). The competition, which is sponsored by the Classical Association of South Africa, is open to undergraduate students every year and to Honours students in even-numbered years. A cash prize of R500 is awarded.

\section{FATE AND DIVINE WORKING IN SOPHOCLES' OEDIPUS REX}

\section{Scheepers (Classical Culture 2, University of South Africa)}

The question of Oedipus' culpability for the parricide and incest that he unwittingly commits has taken on the aspect of a perennial debate. The ambivalence which surrounds this issue is extant even in the work of Aristotle, who, although unable to impose Plato's “categories of moral judgement on the stories of Greek tragedy" (Gagarin 1976:27), due to its effect of the unjust being rewarded and the just being punished, nonetheless, as Plato's successor, rejects both the simple tragic plot and the simple moral plot. That is, Aristotle refutes the 'simplistically' structured tragic plot, which involves a good man coming to misfortune, as completely immoral, and rejects the simple moral plot, in which a bad man succumbs to hardship, as utterly untragic. Arguably, as a result, Aristotle employs the ambiguous word, hamartia, to account for the error of the tragic hero which causes his fall. In the Poetics, this term "subtly...carr[ies] both...a moral meaning so that the hero's fate is just and a nonmoral meaning so that it is tragic" (Gagarin 1976:27). On the basis of this ambiguous issue, namely the question of the 'personal' culpability of the tragic hero, this article will analyze the second stasimon of Sophocles' Oedipus Rex in an attempt to bring the most plausible 'conception' of hamartia in this tragedy into conspicuity. The specific focus of this examination derives, firstly, from the fact that this stasimon "holds a central position in Oedipus [Rex, because it]...follow[s] the elaborate preparatory scenes and immediately preced[es] the rapid march of the action towards its catastrophe" (WinningtonIngram 1980:179), and secondly, from the pervasiveness of dramatic irony in Sophocles' tragedies that, most often, is contained in the words of the Sophoclean chorus. Ultimately, the analysis of this extract, which is principally grounded in the methodological approach of R.P. Winnington-Ingram to Sophoclean dramatic irony, will advance the contention that Oedipus, his heroic temperament notwithstanding, is inherently innocent and undeserving of his fate, which, as such, renders Oedipus Rex a tragedy par excellence. ${ }^{1}$

The themes that are related in the second stasimon of Oedipus Rex comport, though at times rather tenuously, with the expectation that the Sophoclean Chorus should react to the episode that directly precedes its present articulations. Oedipus' and Creon's politically-orientated conflict, which is tempered by the intervention of Jocasta and 'superficially' quelled by the

That is, Oedipus' suffering evokes both pity and fear since his fall is not motivated by any 'conscious' or 'deliberate' transgression on his part, but rather, as this article contends, is inherent in the tragic hero's 'designated' fate and hence enforced by divine working. 
appeal of the Chorus, constitutes the first half of the episode. Accordingly, in the subsequent ode, the Chorus sings of insolence, or hubris, and tyranny - political themes that may have been suggested to them, albeit 'unconsciously', 2 by the recent demoralizing behaviour of Oedipus, which involved both his derision of Teiresias and his treatment of Creon, who suggested the counsels of the seer. In turn, the second part of the episode that precedes this stasimon entails a discussion between Jocasta and Oedipus which reveals both "a strong presumption that Oedipus was... actually impure[, having killed Laius, bedded his wife and become subject to the curse that he himself had pronounced, and]...potentially impure, if the oracle given to him should be fulfilled" (Winnington-Ingram 1980:184). As such, this exchange reveals, firstly, the impiety of Jocasta that is shared by Oedipus when he endorses the queen's scepticism concerning the fulfilment of the oracle given to Laius. Moreover, the discussion also renders the notion that both the actual and potential impurity of Oedipus has been shared by Jocasta, all of which inform the themes that constitute strophe $\alpha$ of the second stasimon.

\section{Strophe $\alpha$}

May destiny still find me winning the praises of reverent purity in all words and deeds sanctioned by those laws of range sublime, called into life throughout the high clear heaven, whose father is Olympus alone; their parent was no race of mortal men, no, nor shall oblivion ever lay them to sleep; the god is mighty in them, and he grows not old. (Jebb 1982:98)

The purity of deeds and words that the Chorus wishes for is inscribed in the laws of the sublime, which govern "human conduct in various fields [that are believed to be of]...particular...concern [to]...the gods[, such as]...relations...with the gods themselves [and] relations with parents" (Winnington-Ingram 1980:185). However, significantly, an impure deed was 'judged' on the basis of its manifestation rather than its motivation, because while the words of Homeric man, such as "nous and thymos [i.e.]...the seeing mind and the emotive mind, [describe both organs and their related functions, there occurs no integration between these]....agitated soul-organ[s] or [their]...function[s]" (Snell 1982:156) that would result in the notion of a composite sense of self or 'soul' that can be held morally responsible for an unjust act. As such, an impure deed is perceived and evaluated by its "external, nonmoral aspect, [and]...not [by]...the internal, moral aspect, of behaviour" (Gagarin 1976:17) that has motivated it. Accordingly, despite the fact that Oedipus transgresses unwittingly, he, upon suspecting himself of wrongdoing, emotes, "I pollute the bed of the slain man with the hands by which he perished. Say, am I vile? Am I not utterly unclean?...I must be banished" [my italics](Jebb 1982:97). Thus, although Oedipus' words appear to reflect a sense of 'moral guilt' derived from the knowledge of the reprehensibility of his previous acts, such a conception is unfounded, as "[a]rchaic greek culture is one in which everyone lives in terms of others, under the eyes and in the esteem of others, where the basis of a personality is confirmed by the extent to which its reputation is known” (Vernant 1991:57).

In turn, the Chorus' prayer for piety that manifests in both deeds and words, is intimated by their adjectival use of 'reverent', and recalls the recently impious behaviour of Jocasta that

2 At this stage the Chorus certainly cannot regard Oedipus as an insolent or hubristic leader as their appeal to him to relent in his argument with Creon, concerning the way in which they are worn out by "the withering of the land, and...the thought that [their]...old sorrows should be crowned by sorrows springing [anew from Oedipus and Creon]” (Jebb 1982: 93), proves successful as the king submits to their request. 
Oedipus, in effect, later endorses and partakes in. That is, upon the news of Polybus' 'natural' death, the man that he believes to be his father, Oedipus asserts, "Why indeed, my wife, should one look to the hearth of the Pythian seer, or to the birds that scream above our heads, on whose viewing I was doomed to slay my sire?” (Jebb 1982:100). The vexation experienced by the Chorus as a result of suspicions of impiety and impurity that, although as yet unconfirmed, would in due course become manifest, is exacerbated by the recollection of Oedipus' exclamation when, earlier, he suspects himself of being the murderer and, by implication, the accursed: "Forbid, forbid, you pure and awful gods, that I should see that day!" (Jebb 1982:97). Thus, his words reveal the gods as pure and deserving of reverence, such that failure, on the part of mortals to render them praise, would ostensibly culminate in the destructive wrath that the Chorus, although obliquely, are anticipating.

Moreover, the 'destiny', or moira, that the Chorus prays may encompass a continued 'reverent purity', should not be considered as a 'force' that benefits man in one instance and abandons him at another. Rather, moira constitutes the "personification of the individual's fate...a law which even the gods...[cannot] break without endangering the equilibrium of existence" (Grimal 1991:278). As such, it in an inescapable force that accompanies man throughout his existence, and constitutes that which "in fact happens or is going to happen to you, which may be good or bad” (Winnington-Ingram 1980:186). Thus, although the Chorus prays for the continuance of a 'good fate' that entails piety and purity, the possibility of this is entirely contingent upon the constitution of one's moira or, in more personified terms, one's daimon. Significantly, these terms, although synonyms, are later in the narrative used in conjunction to describe Oedipus' dusdaimon, or inherently 'bad fate', when the Coryphaeus exclaims to the self-blinded king, "Who is the unearthly foe [or, daimon]...that, with a bound of more than mortal range, has made your ill-starred life his prey?” (Jebb 1982:109). ${ }^{3}$ Similarly, these words are echoed by Oedipus when he decries, "Oh my Fate, how far have you sprung!" (Jebb 1982:109). Therefore, one can conclude that the moira, or destiny, of Oedipus included, at one time, a degree of purity, but that it ultimately, and despite his most arduous efforts, brings irresistible and unspeakable suffering. Accordingly, in the first stanza of the stasimon there exists an accumulation of words such as 'father' and 'parent' that, tinged with irony, intimate Oedipus' unwitting breach of the divinely sanctioned laws of purity - especially in relation to parents - for which, although 'subjectively innocent', he must suffer as, in terms of his 'unknowing' acts, he remains 'objectively' guilty. ${ }^{4}$

3 In other words, Oedipus' moira, which was already the work of an evil daimon, is preyed upon by yet another fatal force.

4 Von Fritz explains that the suffering of the 'subjectively' innocent Oedipus is grounded in the 'unconsciousness' of his acts that, although contradictory to his nature and intentions, are nevertheless abominable, 'objectively-speaking'. In turn, Reinhardt correspondingly argues that "even if one were to imagine that a court composed of gods or men had acquitted Oedipus of all guilt...it would still not help him in the least...for what meaning would such an acquittal have in the face of the contradiction between what he has imagined he is, and what he is?” (Reinhardt 1979: 134). 


\section{Antistrophe $\alpha$}

Insolence breeds the tyrant; insolence, once vainly surfeited on wealth that is not meet nor good for it, when it hath scaled the topmost ramparts, is hurled to a dire doom, wherein no service of the feet can serve. But I pray that the god never quell such rivalry as benefits the state; the god will I ever hold for our protector. (Jebb 1982:98)

Arguably, antistrophe $\alpha$ constitutes the most problematic stanza of the second stasimon, firstly, since its conceptual connection with the preceding stanza is rather tenuous, and secondly, because its description of the fall of the hubristic or 'insolent' man does not correspond with king Oedipus' disposition. This strophe extrapolates on the origin and the fate of the personification of hubris, namely the insolent man, and it seems as though Sophocles is, in the first sentence of the stanza, "playing a variation of a traditional theme [insofar as he states]...that hubris breeds, not koros, nor (as in Aeschylus) new hubris, but...a tyrant” (Winnington-Ingram 1980:189). ${ }^{5}$ As such, although the Greek word for 'tyrant' means no more than 'king', it is inconceivable that the use of the term, both in relation to the context of this stanza and in the light of Sophocles' appropriation of the above-mentioned 'traditional' and arguably 'moralistic' theme, does not possess sinister connotations. Thus, if one accepts that "the connection of thought [of this stanza]...with the preceding [one need not]...be obvious [as,]...on any interpretation[,] the antistrophe is somewhat tangential to the strophe” (Winnington-Ingram 1980:189), then antistrophe $\alpha$ may relate to the first stanza in terms of a contrast between the fallible power of man and the infallibility of the gods in whom the Chorus ultimately places their trust.

The problem which thus arises is the notable discrepancy between the Chorus' overt valorization of Oedipus, whom they deem "first of men, both in life's common chances and when mortals have to do with more than man” (Jebb 1982:78), and their implicit and seemingly 'unconscious' apprehensions with regard to the continued benevolence of their king, as exemplified in their prayer to the archer god for the perpetuation of "such rivalry as benefits the state” (Jebb 1982:98). Significantly, Jebb's translation of the term palaisma as 'rivalry' has been disputed by certain scholars who, instead, translate the Greek word as 'emulation', which then attributes to the term an admixture comprised of the alacrity, intelligence and public spirit that, characteristic of Oedipus, allowed him to solve the riddle of the Sphinx and thereby save the polis of Thebes. The Chorus prays that this 'quality' will once again bring their king "success[, only this time]...in his search for the killers [of Laius. However, ironically, the palaisma that they pray for]...land[s]...him in that very plight to which hubris is supposed to lead" (Winnington-Ingram 1980:191). This conception is inherently paradoxical as it firstly problematizes the stanza's ascription of hubris as the principal source of ruin insofar as it seems that the fall of Oedipus is, contrarily, contingent upon the continuation of the very palaisma that the Chorus advances to prevent such dissolution. Secondly, and diametrically opposed to the above, this problematic imbues the 'innocence' of Oedipus, in terms of his 'personal' culpability

$5 \quad$ Although 'traditionally' perceived as the parent of hubris, the term koros has not only been equated with hubris, but has also been conceived of as the offspring of hubris, in which case it denotes a malapropism of power and wealth. 
for his fall, with an ever-increasing ambiguity, ${ }^{6}$ which is only further augmented when, in the next strophe, certain characteristics of the hubristic man appear to find their apt manifestation in king Oedipus himself.

\section{Strophe $\beta$}

But if a man walks haughtily in deed or word, with no fear of Justice, no reverence for the images of gods, may an evil doom seize him for his ill-starred pride, if he will not win his vantage fairly, nor keep him from unholy deeds, but must lay profaning hands on sanctities. Where such things are, what mortal shall boast any more that he can ward the arrows of the gods from his life? Nay, if such deeds are in honor, wherefore should we join in the sacred dance? (Jebb 1982:98)

This stanza continues the theme of hubris that was first broached in antistrophe $\alpha$, but deviates therefrom insofar as it sets about characterizing the hubristic man via a range of traditional offences. Initially, the 'offender' is delineated by way of a haughtiness in deeds and/or words, the former possibly intimating an unjust disposition towards political subjects and the latter a boastful orientation with regard to personal achievement. However, on both counts, Oedipus appears to be innocent; in the first case, his ostensibly unjust and rash treatment of the unassuming Creon derives from his concern for the welfare of the Polis rather than his desire to safeguard his personal interests, and the king ultimately refrains from carrying out his threats. ${ }^{7}$ Secondly, in terms of arrogance in speech, Oedipus is, once again, guiltless, despite his seemingly hubristic statements, as exemplified in his 'self-acclamation' during his encounter with the suppliants before the palace, namely "I, Oedipus, renowned of all” (Jebb 1982:77). That is, although perhaps perceived as contemptuous by the modern reader, statements such as these were socially acceptable in classical Greece insofar as it was not deemed inappropriate to speak of one's achievements - Oedipus, after all, was “famous for solving the riddle of the Sphinx and[, as such, the above-mentioned claim was considered]...a frank and natural reference to this feat" (Rademeyer 2003:25). In turn, when it is said that the hubristic man does not fear 'justice', the innocence of Oedipus is further amplified insofar as the speech that accompanies his realization that he is the murderer of Laius is saturated with intimations of fear. That is, during his exchange with Jocasta, his words unequivocally denote his increasing anxiety over his wife's descriptions of Laius' murder, as illustrated by phrases such as "I have dread misgivings that the seer can see[;]...I fear that my own lips have been unguarded...[and] my forebodings have advanced so far" (Jebb 1982:95-96). Moreover, the Chorus declares that the insolent man refrains from revering the gods and, as such, Oedipus once again appears blameless - firstly because he "went to Delphi, which put him on the way to his destiny [and]...sent [Creon] to Delphi, which put him on the way to its discovery[, and thirdly, because the 'impiety' in which he partakes with Jocasta was motivated by]...the irony of circumstance rather than traditional sin” (Winnington-Ingram 1980:195). However, from the Chorus' wish for the destiny of the

6 In fact, numerous scholars, including Bernard Knox, have noted the ambiguous play, in this stanza, on the name 'Oedipus', which derives from the words 'know', or 'swell', and 'foot'. That is, in this stanza mention is made that "no service of the feet can serve" (Jebb 1982: 98) to prevent the fall of the hubristic man, which possibly refers to the inevitability of Oedipus' ruin, his previous ability to solve the Sphinx' riddle as a result of his personal insight, which derived, in turn, from his crippled condition, notwithstanding.

7 Cf. note 2. 
offending man to match his deeds in the extent of its adversity, arises the question of whether a corresponding relationship exists between the merit of one's behaviour and the degree of prosperity that is contained in one's fate and, as such, whether Oedipus' fall was, in fact, motivated by his own, albeit unwitting, acts. ${ }^{8}$

Oedipus, although not guilty of the offences that are initially delineated in the stanza, is unequivocally reprehensible in terms of his execution of those odious acts that are subsequently ascribed to the hubristic man. By killing Laius, who is later revealed to be his actual father, and by annexing his position as the Theban king, Oedipus had neither won his position fairly nor refrained from impious deeds. Moreover, he is certainly not guiltless of the charge of 'laying profaning hands on sanctities' due to his marriage with Jocasta, his mother, and their resultant progeny. Despite the fact that he unknowingly committed these acts to which the Chorus, at this stage, are similarly oblivious, only the latter's prayer is heeded as Oedipus is consequently shot down by the arrows of the archer god. ${ }^{9}$

\section{Antistrophe $\beta$}

No more will I go reverently to earth's central and inviolate shrine, no more to Abae's temple or Olympia, if these oracles fit not the issue, so that all men shall point at them with the finger. Nay, King - if thou art rightly called - Zeus all-ruling, may it not escape thee and thine ever-deathless power! The old prophesies concerning Laius are fading; already men are setting them at nought, and nowhere is Apollo glorified with honors; the worship of the gods is perishing. (Jebb 1982:9899)

Of all the stanzas that constitute the second stasimon, antistrophe $\beta$ is the one that is most inextricably linked to the previous episode insofar as it thematizes the Chorus' vexation with both Jocasta's pronounced impiety and the ostensible fallacy of the oracle that was given to Laius. The latter fear derives from the Chorus' view that the non-fulfilment of such oracles would result in the atrophy of religion, as would the lack of retribution against the hubristic offender that was characterized in strophe $\beta$. However, these 'dangers' are revealed as mere spectres when the revelation of the oracle's fulfilment is attended by the 'self-punishment' of the 'hubristic' offender, namely king Oedipus himself. However, the Chorus' prayer is executed "in a perplexity of mind[, because,]... in their perplexity they pray for something which will, in its nature, bring utter disaster upon the king who has earned their loyalty" (Winnington-Ingram 1980:200), as the reestablishment of divine authority will concomitantly result in the annihilation of the mortal king.

8 This 'self-deterministic' perspective diametrically opposes the conception of a 'predetermined' fate, as advanced by Achilles in Homer's Iliad, namely that “there are two great jars that stand on the floor of Zeus's halls and hold his gifts, our miseries one, the other blessings. When Zeus...mixes gifts for a man, now he meets with misfortune, now good times in turn” (Fagles 24. 615-618).

9 Oedipus is unaware of his guilt on all accounts - he was, after all, an exile appointed as the king of Thebes because he "free[d its] folk [by]...ma[king the Sphinx]...mute when [he]...had seized the answer by [his] wit" (Jebb 1982: 86). The extent of his obliviousness to both his slaying of Laius and to his own parentage is exemplified in his heavily ironic declaration that he "will uphold this cause[, i.e. that of discovering the killers of Laius]...even as the cause of [his]...own sire” (Jebb 1982: 83). 
It is said that the significance of the Sophoclean Chorus derives from the fact that their words both implicitly convey the author's interpretation of the tragic text, making the "meaning and coherence of [their]...thought [understandable, and that these words frequently, yet somewhat paradoxically,]...carry a significance beyond...and even contrary to...the...conscious thought [of the Chorus]" (Winnington-Ingram 1980:200). ${ }^{10}$ With this in mind, an overview of the above analysis of the second stasimon, which forms a central part of Oedipus Rex, clarifies some of the reasons for Oedipus' fall or, in other words, facilitates a greater understanding of his hamartia. While the themes broached in the first and the last stanza of the stasimon, namely the transience of 'reverent purity' and the possible weakening of divine will, precipitate from the events of the preceding episode, the reasons for the Chorus' treatment of hubris and its fall in the middle stanzas remain tenuous. That this theme is underpinned by the Chorus' perception of Oedipus' killing of Laius as a hubristic act is inconceivable; ${ }^{11}$ firstly because, as an exile in a foreign land, Oedipus’ behaviour constituted “a justified act of retaliation” (Winnington-Ingram 1980:201), and secondly, since the hubris of which the Chorus sings is grounded in the misuse of kingly power and wealth, both of which Oedipus notably lacked at the time of this fateful incident. Moreover, his motivation for the murder did not involve any desire for the hierarchical position of Laius as, unaware of the identity of his victim, he continued to gain the Theban throne via a completely honourable act of solving the riddle of the Sphinx.

Thus, the most plausible impetus behind the Chorus' thematization of hubris entails Oedipus' rash treatment of both Teiresias and Creon, insofar as his bearing towards them seems to have been grounded in his 'intellectual' self-confidence that, ironically, had only been further augmented by the Theban citizenry's trust in their king's erudite abilities to save the polis yet again. $^{12}$ As such, although the Chorus prays for the continuation of the type of rivalry that benefits the state and that is, presumably, characteristic of their 'good king', their following articulation entails a delineation of 'detrimental' rivalry which appears to intimate that, if Oedipus' hubristic behaviour goes unpunished, the 'death' of religion is at hand. Yet, their conceptions of Oedipus' wrongdoing, as well as his 'befitting' fate, are revealed as unequivocally erroneous through numerous ironies to which this article has already alluded. That is, while the Chorus fear that their king may fall as a result of his abuse of the power and wealth that he has been granted, Oedipus' destruction derives from acts that he had unwittingly committed prior to his assumption of the throne. Moreover, while the Chorus prays for a 'beneficial' rivalry to continue, it is, above all, this orientation of Oedipus, namely a persistent striving for truth in the interest of the polis, which leads him to disaster. Similarly, although the Chorus plead with Apollo for protection, it is "Apollo...that br[ings]...the...woes of [Oedipus]...to pass” (Jebb 1982:110). Furthermore, although Oedipus is 'subjectively innocent'

10 This article observes the existence of a perennial debate concerning the role of the Chorus within the dramaturgical text and contends, with Aristotle, that the Sophoclean Chorus is frequently involved in the dramatic action and thus, concomitantly, possesses a limited view not unlike that of other actors who are similarly restricted in their perceptions by the specific dramatic situation in which they happen to find themselves.

11 At this stage, Teiresias has publicly declared Oedipus the murderer and the latter has similarly suspected himself of the crime.

12 Hornblower similarly asserts that Oedipus is "quickwitted, meddlesome, and doomed because of those precise elements in his greatness" (Hornblower 1992:220). Cf. note 9. 
of those acts that are attributed to the hubristic man, he is seized by an evil moira, punished by the archer god and "reserved for some strange doom” (Jebb 1982:112). Thus, having executed those deeds that are deemed impious and impure, Oedipus cannot circumvent the divine wrath that is forthcoming, yet his is not the "punishment of deliberate sin, but punishment of the unwitting sinner whose punishable acts are part of his destiny from the beginning and are performed in utter innocence” (Winnington-Ingram 1980:203). ${ }^{13}$

Hence, this article asserts, against scholars such as Scodel, that Oedipus' dilemma entails a tragedy of fate and divine working rather than one determined by an admixture of silence and lies, oracular speech, coincidence and the king's own nature. As such, if one were to find any 'moral' content in the tragic fate of Oedipus, it would be that the text provokes men "to realize the fragility of human fortunes and the vast sea of ignorance in which they swim” (WinningtonIngram 1980:204). Ultimately, however, the tragic figure of Oedipus was as fated to comprehend the unearthly riddle of the Sphinx as he was destined to misconstrue his own identity, as presaged by his flight from both the temple at Delphi and, by implication, the imperative of gnothi sauton, ${ }^{14}$ in a fruitless attempt to evade his evil moira.

\section{BIBLIOGRAPHY}

Burkert, W 1985. Greek Religion. (J Raffan, Trans.). Massachusetts: Harvard University Press. Freud, S 1966. 'Oedipus Rex’, In Sophocles. (T Woodard, ed). New Jersey: Prentice-Hall, Inc. Gagarin, M 1976. Aeschylean Drama. Los Angeles: University of California Press, Ltd.

Grimal, P 1991. The Penguin Dictionary of Classical Mythology. London: Clays Ltd, St Ives plc.

Homer 1991. The Iliad. (R Fagles Trans.). Harmondsworth: Penguin Books Ltd.

Hornblower, S 1992. 'Greece: The History of the Classical Period', In Greece and the Hellenistic World. London: Oxford University Press.

Nietzsche, F 1966. 'Sophoclean Tragedy'. In Sophocles. (T Woodard, ed). New Jersey: Prentice-Hall, Inc. Rademeyer, J C 2003. Greco-Roman Tragedy: Sophocles' Oedipus the King, study guide 1 for CCL821M. Pretoria: University of South Africa.

Reinhardt, K 1979. Sophocles. (H Harvey \& D Harvey Trans.). Oxford: Basil Blackwell.

Snell, B 1982. The Discovery of the Mind in Greek Philosophy and Literature. New York: Dover Publications, Inc.

Sophocles 1982. 'Oedipus the King'. (R.C. Jebb, Trans.). In The Complete Plays of Sophocles. (Moses Hadas, ed). New York: Bantam Books.

Vernant, J-P 1991. Mortals and Immortals: Collected Essays. (Froma I Zeitlin, ed). New Jersey: Princeton University Press.

Winnington-Ingram, R P 1980. Sophocles: An Interpretation. Oxford: Cambridge University Press.

13 Both Nietzsche and Freud comport with this conception; while the former claims "the dialectical reversal [of fortune in Oedipus Rex to be]...due to the gods" (Nietzsche 1966:17), the latter names this work "a tragedy of destiny” (Freud 1966: 102).

14 Engraved in the sixth century in the temple at Delphi, this "saying...in particular express[es] the spirit of Apollo, which is wisdom and morality at once:... know yourself[, or,]...know that you are not a god" (Burkert 1985: 148). 